\title{
Effects of Different Exercise Intensities on GLUT-4 and GRP-78 Protein Expression in Soleus Muscle of Streptozotocin-Induced Diabetic Rats with Caffeine Oral Administration
}

\author{
Jae-Suk Yoon and Jin-Hwan Yoon* \\ Department of Sports Science, Hannam University, Dajon 133, Korea
}

Received August 9, 2004 /Accepted August 23, 2004

\begin{abstract}
This study investigated the response of GLUT-4 and GRP-78 protein expression in soleus muscle of Streptozotocin-induced diabetic rats with caffeine oral administration by imposing different exercise intensities. Rats were randomly divided into 5 groups $(n=6$ in each group): diabetic group (D), diabetic-caffeine group (DC), diabetic-caffeine group with low intensity exercise (DCL), diabetic-caffeine group with moderate intensity exercise (DCM) and diabetic-caffeine group with high intensity exercise $(\mathrm{DCH})$. The rats in DCL, DCM and DCH groups were exercised acutely by treadmill running for 8 meter $/ \mathrm{m}, 16$ meter $/ \mathrm{m}$ and 25 meter $/ \mathrm{m}$, respectively. Little difference in GLUT-4 protein expression was shown in DC and DCL compared to D. GLUT-4 protein expression was decreased in DCM and increased in DCH was observed. GRP-78 protein expressions in DCL, DCM and DCH were little lower than that of D. An increase in GRP-78 protein was observed in DC. Improved insulin sensitivity with acute high intensity exercise gives the rats important therapy that lowers insulin requirement. This improvement of insulin sensitivity for glucose transport in skeletal muscle results from translocation of the GLUT-4 protein from the endoplasmic reticilum to the cell surface and increase in total quantity of GLUT-4 protein. It is not clear what mechanism reduced GRP-78 protein level in exercise group. It is merely conjectured that caffeine-induced lipolysis provided cells with energy in abundance and this relieved stress which cells are subjected to receive when performing exercise.
\end{abstract}

Key words - diabetes rats, GLUT-4 protein, GRP-78 protein, caffeine, exercise intensities

Rat skeletal muscle are extremely heterogeneous with respect to their metabolic capacities, Early studies also show this to be so for glucose uptake and insulin binding, with greater insulin-stimulated glucose transport occurring in an oxidative muscle such as soleus when compared with more glycolytic types of muscles such as plantaris [3,4] with the discovery that glucose transporter 4 (GLUT-4) content was greater in red then in white muscles[12,14,20]. Skeletal muscle is the primary site responsible for insulin-mediated glucose utilization[2,6] and contributes to the postpranial hyperglycemia observed in patients with diabetes[6,9]. Glucose is transported into the cell through the plasma membrane and T-tubules using glucose transporter proteins[17]. GLUT-1 and GLUT-5 protein are present in low quantity and do not transport glucose in response to insulin signaling and exercise[17]. Therefore, GLUT-4 protein is a good indicator showing glucose disposal reaction to exercise.

A large number of studies have documented a positive effect of exercise training on skeletal muscle GLUT-4 protein concentration. It has been shown in healthy rats[24], insulin

\footnotetext{
*Corresponding author

Tel : +82-42-629-7990 Fax : +82-42-629-8402

E-mail : yoonih@hannam.ac.kr
}

resistance rats[1], young healthy humans[23], previously sedentary middle-aged men, and individuals with impaired glucose homeostasis and non-insulin-dependant diabetes mellitus (NIDDM)[8,16]. Furthermore, this rise in GLUT-4 protein concentration has been found to significantly correlate with an improvement in insulin-stimulated muscle glucose transport[1,5], and to have a positive effect on the ability of insulin to control blood glucose as assessed by the oral glucose tolerance test (OGTT)[11] and the euglycemic clamp technique[15].

Also, Glucose-regulated protein 78 (GRP-78) is a molecular chaperone which is continuously expressed. GRP-78 protein expression is increased under a diversity of stressful conditions including glucose deprivation, oxidative stress, and hypoxia[25]. Induction of GRP-78 protein is vital to protecting cells against their death.

Caffeine is the most widely consumed ergogenic aids among athletes. Regular meals provide a little caffeine but athletes expecting ergogenic boost from caffeine are known to take caffeine[26,27]. Caffeine enhances exercise performance by increasing FFA mobilization during prolonged exercise but caffeine can produce restlessness, headaches, insomnia, and premature left ventricular contractions by stimulating central nervous system[22]. Guenther Boden[13] 
reported that elevated FFA by caffeine, and the like causes insulin resistance by inhibiting GLUT-4 protein gene expression.

Previous studies[17,18,25] reported that exercise induces GLUT-4 and GRP-78 protein expression and an increase in GLUT-4 protein level enhances insulin resistance. Thus, the negative effects associated with caffeine and diabetes on insulin sensitivity and glucose transporters could be mediated by exercise[13,17].

Therefore, This study investigated the response of GLUT-4 and GRP-78 protein expression in soleus muscle of Streptozotocin-induced diabetic rats with caffeine oral administration by imposing different exercise intensities.

\section{Methods}

\section{Animals}

30 male F344 rats weighting 250 - 260 g were used in this experiment. The rats were housed under controlled temperature $\left(20 \pm 2^{\circ} \mathrm{C}\right)$ and lighting $(07: 00 \sim 19: 00 \mathrm{~h})$ conditions with food and water available ad libitum. Rats were randomly divided into 5 groups $(n=6)$ : diabetic group (D), diabeticcaffeine group (DC), diabetic-caffeine group with low intensity exercise (DCL), diabetic-caffeine group with moderate intensity exercise (DCM) and diabetic-caffeine group with high intensity exercise (DCH).

\section{Induction of diabetes}

Diabetes was induced by an intraperitoneal injection of Streptozotocin $(65 \mathrm{mg} / \mathrm{kg}$ b.w in $0.05 \mathrm{M}$ sodium citrate, $\mathrm{pH}$ 4.5; Sigma, St. Louis, MO, USA). Two days after injection, plasma glucose concentration was estimated from a tail vein blood sample. Animals were considered diabetic if the glucose levels were greater than $300 \mathrm{mg} / \mathrm{dl}[8]$.

\section{Caffeine oral administration and exercise protocol}

Caffeine was administrated through gastric tube $(5 \mathrm{mg} / \mathrm{kg}$ b.w in Nacl) one hour before their exercise. D and DC were administrated 1 hour before their sacrifice. The exercise protocol is as follows in Table 1.

\section{Muscle sample preparation}

Immediately after the exercise, Ketamine $(80 \mathrm{mg})$ and Rompun ( $5 \mathrm{mg}$ ) were injected by an intraperitoneal injection. To avoid being adulterated with blood of muscle, blood ( 10 $\mathrm{ml}$ ) was collected from heart before the excision. Soleus muscle
Table 1. Exercise protocol in each group

\begin{tabular}{|c|c|c|c|c|}
\hline \multirow[b]{2}{*}{ Group } & \multirow[b]{2}{*}{$\mathrm{N}$} & \multicolumn{2}{|c|}{ Intensity } & \multirow{2}{*}{$\begin{array}{l}\text { Exercise time } \\
\text { (min) }\end{array}$} \\
\hline & & $\begin{array}{c}\text { speed } \\
\text { (meter/min) }\end{array}$ & $\begin{array}{l}\text { grade } \\
(\%)\end{array}$ & \\
\hline $\mathrm{D}$ & 6 & no & & \\
\hline DC & 6 & no & & \\
\hline DCL & 6 & 8 & 0 & 30 \\
\hline DCM & 6 & 16 & 0 & 30 \\
\hline $\mathrm{DCH}$ & 6 & 25 & 0 & 30 \\
\hline
\end{tabular}

D: diabetic group, DC: diabetic-caffeine group, DCL: diabeticcaffeine group with low intensity exercise, DCM: diabeticcaffeine group with moderate intensity exercise, $\mathrm{DCH}$ : diabeticcaffeine group with high intensity exercise.

was obtained from the hindlimb. Muscle sample was stored at $-80^{\circ} \mathrm{C}$ until analysis.

\section{Western Blot}

Muscle was washed with ice-cold PBS; and sonicated under $50 \sim 200 \mu \mathrm{l}$ of triton lysis buffer (20 mM Tris, $\mathrm{pH} 7.4,137 \mathrm{mM}$ $\mathrm{NaCl}, 25 \mathrm{mM} \beta$-glycerophosphate, $\mathrm{pH} 7.14,2 \mathrm{mM}$ sodium pyrophosphate, 2 mM EDTA, $1 \mathrm{mM} \mathrm{Na} 3 \mathrm{VO} 4,1 \%$ Triton X-100, $10 \%$ glycerol, $5 \mu \mathrm{g} / \mathrm{ml}$ leupeptin, $5 \mu \mathrm{g} / \mathrm{ml}$ aprotinin, $3 \mu \mathrm{M}$ benzamidine, $0.5 \mathrm{mM}$ DTT, $1 \mathrm{mM}$ PMSF). Ten micrograms of proteins were used for Western analysis using anti-GLUT 4 antibody (H-100, Santa Cruz Biotech.) and anti-GRP 78 antibody (SPA-826, Stressgen). Electrophoresis of membrane proteins was preformed using a $12 \%$ SDS-polyacrylamide gel (SDS-PAGE) and then the proteins were electrophoretically transferred to polyvinylidene difluoride (PVDF) membrane (Pall Corporation, U.S.A). Blocking of unspecific bindings was done using 3\% BSA, $0.1 \%$ Tween 20 in TBS buffer for $1 \mathrm{~h}$ at room temperature; then, the membrane was incubated overnight at $4^{\circ} \mathrm{C}$. The membrane was washed and then incubated a solution containing a 1:1000 dilution of polyclonal antibodies specific for the C-terminal of rat Glut 4 and GRP 78 for one and half hour at room temperature. The membrane was washed again and then incubated in a solution containing a 1:1000 dilution of horseradish peroxidaseconjugated anti-rabbit IgG (Santa Cruz, U.S.A) for one and half hour at room temperature. After washing, blotting proteins were visualized using Western blotting detection system, and then exposed to a Kodak Scientific Imaging Film (Esteman Kodak Co., U.S.A).

\section{Results}

This study examined the response of GLUT-4 and GRP-78 protein expression in soleus muscle of Streptozotocin-induced 
diabetic rats with caffeine oral administration by imposing different exercise intensities.

\section{GLUT-4 protein expression}

The changes of GLUT-4 protein expression in soleus muscle of Streptozotocin-induced diabetic F344 rats with caffeine administration depending on different exercise intensities are shown in Fig. 1. Little difference was shown in DC and DCL compared to D. GLUT-4 protein expression was decreased in DCM and an increase of GLUT-4 protein in DCH was observed.

\section{GRP-78 protein expression}

The changes of GRP-78 protein expression in soleus muscle of Streptozotocin-induced diabetic F344 rats with caffeine administration depending on different exercise intensities are shown in Fig. 2. GRP-78 protein levels in DCL, DCM and $\mathrm{DCH}$ were little lower than that of $\mathrm{D}$. An increase in GRP-78 protein was observed in DC. It is clear that exercise reduced GRP-78 protein expression in Streptozotocininduced diabetic rats with caffeine administration.

\section{Discussion and Conclusion}

Caffeine administration impairs insulin-stimulated glu- cose uptake and glycogen syntheses activity in exercised muscle and this is the major reason causing reduction of glucose disposal[23]. Carbohydrate content is a major indicator determining endurance exercise capacity and when muscle glycogen is depleted following endurance exercise, fatigue and exhaustion are easily come. With muscle glycogen compensated, exercise capacity is enhanced[17].

Previous studies[17,24] showed a positive relationship between exercise ability and caffeine administration. However, No study reported the changes of GLUT-4 and GRP-78 protein expression in streptozotocin-induced diabetic rats with caffeine administration depending on different exercise intensities. The study investigated, therefore, the effect of acute different exercise intensities on GLUT-4 and GRP-78 protein in skeletal muscle of Streptozotocin-induced diabetic rats with caffeine administration.

In this study, GLUT 4 protein level in DCH showed the most significant increase in volume. Improved insulin sensitivity with acute high intensity exercise gives the rats important therapy that lowers insulin requirement. This improvement of insulin sensitivity for glucose transport in skeletal muscle results from translocation of the GLUT-4 protein from the endoplasmic reticilum to the cell surface and increase in total quantity of GLUT-4 protein[11,17].

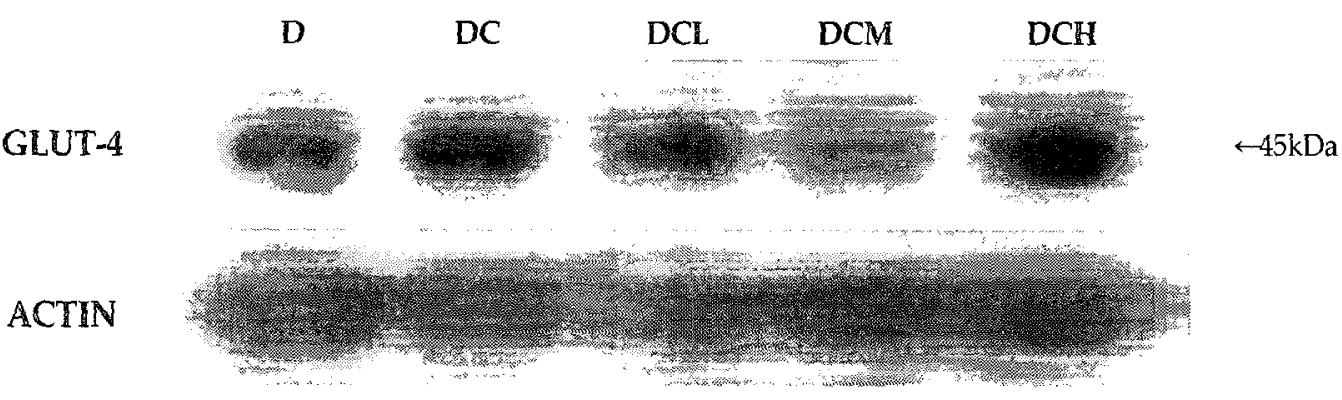

Fig. 1. GLUT-4 protein expression in soleus muscle. D: diabetic group, DC: diabetic-caffeine group, DCL: diabetic-caffeine group with low intensity exercise, DCM: diabetic-caffeine group with moderate intensity exercise, DCH: diabetic-caffeine group with high intensity exercise.

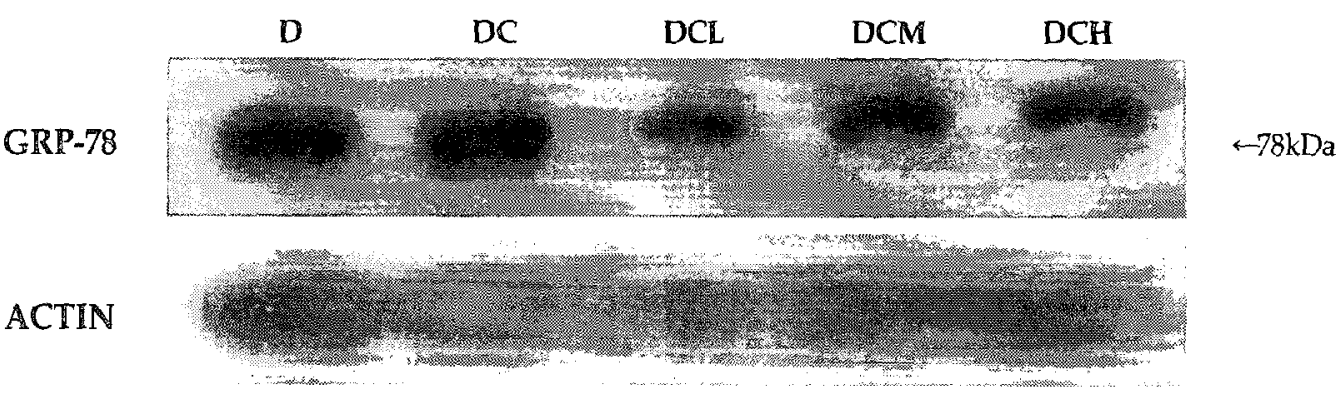

Fig. 2. GRP-78 protein expression in soleus muscle. D: diabetic group, DC: diabetic-caffeine group, DCL: diabetic-caffeine group with low intensity exercise, DCM: diabetic-caffeine group with moderate intensity exercise, DCH: diabetic-caffeine group with high intensity exercise. 
This mechanism explains why DCH shows higher contents of GLUT-4 protein.

Many studies suggest that an increase in muscle GLUT-4 protein concentration should have a positive influence on the insulin resistance state. It should be noted, however, that insulin resistance associated with NIDDM is not due to a deficient muscle GLUT-4 protein concentration[1,18,19], but involves a reduced ability of insulin to translocate GLUT-4 protein from its intracellular storage site to the plasma membrane[3,15]. Exercise training has not been found to correct this defect. However, it has been demonstrated in the obese Zucker rat that the increase in GLUT-4 protein following training compensates for the defect in translocation and improves insulin-stimulated muscle glucose transport[3]. The mechanism of compensation is not fully understood, but appears to involves positioning of newly expressed GLUT-4 protein at a site closely associated with the plasma membrane and distal to the defect in translocation. Therefore, with insulin stimulation, there is an increase in GLUT-4 protein incorporation into the plasma membrane and increase in glucose transport.

Also, Watchman et al[24] reported that increased lipolysis following caffeine ingestion is related to retarded insulin secretion. Also, epinephrine stimulated by caffeine acts as an antagonist of the adenosine receptors which suppress lipolysis. Disturbed adenosine receptor increases cellular levels of the cyclic AMP. Cyclic AMP activates homonesensitive lipases to spur free fatty acid to be released[17,23].

GRP-78 protein is expressed when exposed to stress. Cells survive under various stressful conditions by expressing stress proteins[14]. Jill et al[14] also reported the embryos of rodent exposed to hypoglycemia condition show malformations including heart and craniofacial defect. In the study by Song et al[20], GRP-78 protein level is increased after cell's being exposed to hypoxia.

In this study, a unique increase of GRP-78 protein in DC was observed and all exercise groups showed reduced GRP-78 protein. It is not clear what mechanism reduced GRP-78 protein level in exercise group. It is merely conjectured that caffeine-induced lipolysis provided cells with energy in abundance and this relieved stress which cells are subjected to receive when performing exercise.

\section{References}

1. Banks EA, Brozinick JT Jr, Yaspelkis BB 3rd, Kang HY and Ivy JL. 1992. Muscle glucose transport, GLUT-4 content, and degree of exercise training in obese Zucker rats. Am J Physiol. 263(5 Pt 1), E1010-5.

2. Baron AD, Brechtel G, Wallace P and Edelman SV. 1988. Rates and tissue sites of non-insulin- and insulin-mediated glucose uptake in humans. Am J Physiol. 255, E769-E774.

3. Bonen A, Tan MH and Watson-Wright WM. 1984. Effects of exercise on insulin binding and glucose metabolism in muscle. Can J Physiol Pharmacol. 62(12), 1500-4.

4. Bonen A, Tan MH and Watson-Wright WM. 1981. Insulin binding and glucose uptake differences in rodent skeletal muscles. Diabetes. 30(8), 702-4.

5. Brozinick JT Jr, Etgen GJ Jr, Yaspelkis BB 3rd, Kang HY and Ivy JL. 1993. Effects of exercise training on muscle GLUT-4 protein content and translocation in obese Zucker rats. Am J Physiol. 265(3 Pt 1), E419-27.

6. DeFronzo RA, Jacot E, Jequier E, Maeder E, Wahren J and Felber JP. 1981. The effect of insulin on the disposal of intravenous glucose: results from indirect calorimetry and hepatic and femoral venous catheterization. Diabetes. 30 , 1000-1007.

7. Defronzo RA, Simonson D and Ferrannini E. 1982. Hepatic and peripheral insulin resistance: a common feature of type II (non-insulin-dependent) and type I (insulin dependent) diabetes mellitus. Diabetologia. 23, 313-319.

8. Dela F, Ploug T, Handberg A, Petersen LN, Larsen JJ, Mikines KJ and Galbo H. 1994. Physical training increases muscle GLUT4 protein and mRNA in patients with NIDDM. Diabetes. 43(7), 862-5.

9. Dohm GL, Tapscott EB, Pories WI, Dabbs DJ, Flickinger EG, Meelheim D, Fushiki T, Atkinson SM, Elton EC and Caro JF. 1988. An in vitro human muscle preparation suitable for metabolic studies: decreased insulin stimulation of glucose transport in muscle from morbidly obese and diabetic subjects. J Clin Invest. 82, 486-494.

10. Frank, Brosius. 2003. Low-dose streptozotocin induction protocol (Mouse). Animal Model of Diabetic Complications Consortium.

11. Garvey WT, Maianu L, Hancock JA, Golichowski AM, Baron A. 1992. Gene expression of GLUT4 in skeletal muscle from insulin-resistant patients with obesity, IGT, GDM, and NIDDM. Diabetes. 41(4), 465-75.

12. Goodyear LJ, Hirshman MF, Smith RJ and Horton ES. 1991. Glucose transporter number, activity, and isoform content in plasma membranes of red and white skeletal muscle. Am J Physiol. 261(5 Pt 1), E556-61.

13. Guenther Boden. 2001. Obesity, free fatty acids, and insulin resistance. Current opinion in endocrinology $\mathcal{E}$ diabetes. 8(5), 235-239.

14. Henriksen EJ, Bourey RE, Rodnick KJ, Koranyi L, Permutt MA and Holloszy JO. 1990. Glucose transporter protein content and glucose transport capacity in rat skeletal muscles. Am J Physiol. 259(4 Pt 1), E593-8.

15. Houmard JA, Egan PC, Neufer PD, Friedman JE, Wheeleer WS, Israel RG and Dohm GL. 1991. Elevated skeletal muscle glucose transporter levels in exercise-trained middle-aged men. American Journal of Physiology. 261, 437-443.

16. Houmard JA, Shinebarger MH, Dolan PL, Leggett-Frazier 
N, Bruner RK, McCammon MR, Israel RG and Dohm GL. 1993. Exercise training increases GLUT-4 protein concentration in previously sedentary middle-aged men. $A m$ J Physiol. 264(6 Pt 1), E896-901.

17. John W. Kennedy, Michael F. Hirshman, Ernest V. Gervino, Jeffrey V. Ocel, R. Armour Forse, Stephen J. Hoenig, Doron Aronson, Laurie J, Goodyear, and Edward S. Horton. 1999. Acute exercise induces GLUT4 Translocation in Skeletal Muscle of normal human subjects and subjects with type 2 diabetes. Diabetes. 48, 1-6.

18. Jill A. Barnes, Ida W. Smoak, and Stacy Branch. 1999. Expression of glucose-regulated proteins (GRP78 and GRP94) in hearts and fore-limb buds of mouse embryos exposed to hypoglycemia in vitro. Cell siress $\mathcal{E}$ chaperones. 4(4), 250-258.

19. Kelley DE, Mintun MA, Watkins SC, Simoneau JA, Jadali F, Fredrickson A, Beattie J and Theriault R. 1996. The effect of non-insulin-dependent diabetes mellitus and obesity on glucose transport and phosphorylation in skeletal muscle. J Clin Invest. 15;97(12), 2705-13.

20. Kern M, Wells JA, Stephens JM, Elton CW, Friedman JE, Tapscott EB, Pekala PH and Dohm GL. 1990. Insulin responsiveness in skeletal muscle is determined by glucose transporter (Glut4) protein level. Biochem J. 1;270(2), 397-400.

21. Lund S, Vestergaard $\mathrm{H}$, Andersen PH, Schmitz O, Gotzsche LB and Pedersen O. 1993. GLUT-4 content in plasma membrane of muscle from patients with non-insulindependent diabetes mellitus. Am J Physiol. 265(6 Pt1), E889-97.

22. McArdle William D, Katch Frank I and Katch Victor L. 2001. Exercise Physiology. Lippincott Williams \& Wilkins. 84, 143.

23. Phillips SM, Han XX, Green HJ, Bonen A. 1996. Increments in skeletal muscle GLUT-1 and GLUT-4 after endurance training in humans. Am J Physiol. 270(3 Pt 1), E456-62.

24. Ploug T, Stallknecht BM, Pedersen O, Kahn BB, Ohkuwa T, Vinten J and Galbo H. 1990. Effect of endurance training on glucose transport capacity and glucose transporter expression in rat skeletal muscle. Am J Physiol. 259(6 Pt 1), E778-86.

25. Song Min Sup, Park Yong Keun, Lee Je-Ho and Park Kyoungsook. 2001. Induction of glucose-regulated protein 78 by chronic hypoxiz in human gasric tumor cells through a protein kinase C- $\varepsilon / E R K / A P-1$ signaling Cascade. Cancer Research. 61, 8322-8330.

26. Spriet LL. 2000. Caffeine protentiates low-frequency skeletal muscle force in habitual and nonhabitual caffeine consumers. Int J Sport Nutr. 5, S84-S99.

27. Terjung RL, Clarkson PM, Eichner ER, Greenhaff PL, Hespel $P$, Israel RG, Kraemer WJ, Meyer RA, Spriwt LL, Tarnopolsky MA, Wagenmarkers AJM and Williams MH. 2000. The physiological and health effects of oral creatine supplementation. Med Sci Sports Exerc. 32, 706-717.

28. Thong FS, Derave W, Kiens B, Graham TE, Urso B, Wojtaszewski JF, Hansen BF and Richter EA. 2002. Caffeine-induced impairment of insulin action but not insulin signaling in human skeletal muscle is reduced by exercise. Diabetes. 51, 583-590.

29. Watchman A, Hattner RS, George B and Bernstein DS. 1970. Effects of decaffeineated and nondecaffeinated coffee ingestion on blood glucose and plasma radioimmunoreactive insulin responses to rapid intravenous infusion of glucose in nomal men. Metabolism. 19, 539-546. 


\section{초록 : 카페인 경구투여가 운동강도 차이에 따른 당뇨유발 흰쥐 가자미근의 GLUT4 및 GRP78 단백 질 발현에 미치는 영향}

\section{윤재석 · 윤진환*}

(한남대학교 생활체육학과)

본 연구는 운동강도 차이에 따른 카페인 구강 투여가 STZ-유발 당뇨 쥐 가자미근에서 GLUT-4와 GRP-78 단백질 발현에 미치는 영향을 규명하기 위하여 F344계 수컷 흰쥐를 무작위 표본추출에 의하여 당뇨유발군 $(\mathrm{n}=6)$, 당뇨유발-카페인 투여군 $(\mathrm{n}=6)$, 당뇨유발-카페인투여 저강도운동군 $(\mathrm{n}=6)$, 당뇨유발-카페인투여 중강도 운동군 $(\mathrm{n}=6)$, 그리고 당뇨유발-카페인투여 고강도 운동군 $(\mathrm{n}=6)$ 으로 분류하였다. 저강도 운동은 트레드밀 경 사도 $0 \%$ 에서 $8 \mathrm{~m} / \mathrm{min}$ 속도로, 중강도 운동은 트레드밀 경사도 $0 \%$ 에서 $16 \mathrm{~m} / \mathrm{min}$ 속도로, 고강도운동은 트레드밀 경사도 $0 \%$ 에서 $25 \mathrm{~m} / \mathrm{min}$ 속도로 30 분간 1회 운동을 실시하였다. GLUT-4 단백질 발현은 당뇨군에 비해서 당뇨유발군-카페인 투여군과 당뇨유발-카페인투여 저강도 운동군에서 차이가 없었으며, 당뇨유발-카 페인투여 중강도 운동군에서는 다소 감소하였으나 당뇨유발-카페인투여 고강도 운동군에서 증가하였다. GRP-78 단백질 발현은 당뇨군에 비해서 당뇨유발-카페인투여 저강도 운동군, 당뇨유발-카페인투여 중강도 운동군, 그리고 당뇨유발-카페인투여 고강도 운동군에서 감소하였으나, 당뇨유발-카페인 투여군에서는 다소 증가한 것으로 나타났다. 고강도 일회성 운동이 인슐린 민감도를 개선시켜 인슐린 요구랑을 낮추는데 이러한 효과는 내형질세망에서 세포막으로의 GLUT-4 단백질의 전이와 GLUT-4 단백질 양의 증가 때문이다. 운동군에 서의 GRP-78 단백질이 감소된 기전은 정확히 밝힐 수는 없지만, 카페인으로 인한 지질 동원이 운동 시 작업 근의 세포에 많은 에너지를 공급하여 세포가 받는 스트레스를 완화시켜 주었기 때문이라고 추측된다. 